\title{
Latitude Gradients and Secular Trends in Sex Ratios at Birth: Europe and North America and a Global Overview \\ V Grech
}

\begin{abstract}
Objective: In all continents, latitude gradients and secular trends have been found in the male-female ratio at birth (M/F: male births divided by total births), which is anticipated to approximate 0.515 .

Methods: Annual national data for countries comprising Europe and North America for male and female live births were obtained from the World Health Organisation and analysed with contingency tables.

Results: This study analysed 397278548 live births. An overall decreasing trend in M/F was found $(\mathrm{p}<0.0001)$. A latitude gradient was also noted, with more males being born in southern, warmer latitudes in Europe. The converse occurred in North America, with more males born in northern latitudes $(\mathrm{p}<0.0001)$. There was an overall deficit of 2053687 male births based on an anticipated $\mathrm{M} / \mathrm{F}$ of approximately 0.515 . The declining $\mathrm{M} / \mathrm{F}$ trend has reversed over 2000-9 in Mexico stabilised in the United States. M/F in the North American continent was unaffected following the Chernobyl event of 1986. There was a significant rise in $\mathrm{M} / \mathrm{F}$ in Central Europe only in 1987 returning to the previous baseline over the following two years.
\end{abstract}

Conclusion: $\mathrm{M} / \mathrm{F}$ is decreasing in Europe and North America, in contrast with the rising $\mathrm{M} / \mathrm{F}$ previously found in Asia, South America and the post-Soviet states. The North American $\mathrm{M} / \mathrm{F}$ latitude gradient is similar to that found in South America, with increasing $\mathrm{M} / \mathrm{F}$ in higher and colder latitudes. Europe's latitude gradient is similar to that of Asia's, with more males born closer to the equator. No facile explanation/s for these findings are apparent.

Keywords: Birth rate/*trends, Europe, infant, newborn, North America, sex ratio

From: Department of Paediatrics, Mater Dei Hospital, Malta.

Correspondence: Professor V Grech, Department of Paediatrics, Mater Dei Hospital, Malta. E-mail: victor.e.grech@gov.mt 


\section{INTRODUCTION}

In humans, gender is determined at conception and male births occur slightly in excess $(1,2)$. The male to female ratio of live births is expressed (albeit technically incorrectly) as the ratio of male live births divided by total live births $(\mathrm{M} / \mathrm{F})$. This is expected to approximate 0.515 in humans, with $3 \%$ more liveborn boys than girls $(1,2)$. The reason/s for this discrepancy are uncertain but the factors that have been implicated as causing this imbalance and influencing it are legion $(1,2)$.

The maternal and paternal exposure to most toxins and stressors results in a male deficit $(1,2)$, and this is explained by the Trivers-Willard hypothesis which argues that females in poor condition are somewhat likelier to produce female offspring as these are more likely to survive into adulthood and reproduce, passing on their maternal genetic heritage (3). This is achieved through preferential, gender-selective spontaneous abortions in the context of stressful ambient conditions. This selects female over male offspring. Thus, such mothers are less likely to produce frail male offspring that may not survive to reproductive age, and who, if surviving to adulthood, would have to compete against other males. On the other hand, females in good condition are likelier to select for male offspring as under favourable conditions, males can sire large numbers of offspring. The only adverse environmental factor which consistently elevates $\mathrm{M} / \mathrm{F}$ is radiation (4).

\section{Secular variation in $\mathbf{M} / \mathbf{F}$}

$\mathrm{M} / \mathrm{F}$ is known to undergo secular variations (5), and several studies have shown that $\mathrm{M} / \mathrm{F}$ is declining in the Europe and North America (6).

\section{Latitude variation in $\mathrm{M} / \mathrm{F}$}

$\mathrm{M} / \mathrm{F}$ has also been shown to exhibit a latitude gradient. M/F increases with decreasing latitude in Europe and increases with increasing latitude in the North American continent $(7,8)$.

\section{Chernobyl}


Radiation is known to increase $\mathrm{M} / \mathrm{F}$ and this has been broadly shown in Europe after the Chernobyl disaster of $1986(9)$.

This study identifies secular trends and latitude gradients in $\mathrm{M} / \mathrm{F}$ in Europe and North America, and compares these with trends recently described trends in other continents over the past 60 years. Any potential effects of the Chernobyl event are also sought.

\section{METHODS}

\section{Data sources}

All data analysed (and compared in the discussion) is derived from a World Health Organization (WHO) dataset. Some missing years were acquired from the Eurostat online database (10). Annual male and female live births were obtained directly from a WHO mortality database (WHO Statistical Information System - WHOSIS) for the period 19502009 (11).

\section{Geographical division}

Countries were allocated as per table 1. Missing data was acquired from the Eurostat online database. Residual missing years are indicated.

Mater Dei Hospital and the Malta Medical School do not have an Institutional Review Board (IRB), so approval could not be sought from said board. Ethical approval was not required as this study analysed a large and anonymous WHO database.

\section{Statistics}

Excel was used for data entry, overall analysis and charting. The quadratic equations of Fleiss were used for exact calculation of $95 \%$ confidence intervals (CI) for ratios (12). Chi tests and chi tests for trends for annual male and female births were applied by using the Bio-Med-Stat 
Excel add-in. Excel's slope() function was used to determine direction of trends (increasing or decreasing $\mathrm{M} / \mathrm{F}$ ). The null hypothesis is that there were no significant geographical or secular differences in $\mathrm{M} / \mathrm{F}$. A $\mathrm{p}$ value $\leq 0.05$ was taken to represent a statistically significant result.

\section{RESULTS}

\section{Secular trends}

This study analysed 397278548 live births. Five year total live births and sex ratios at births, in 5 year intervals, are shown in table 2 . An overall decreasing trend in $\mathrm{M} / \mathrm{F}$ was found in almost all regions (table 3).

\section{Latitude gradients}

A clear latitude gradient for $\mathrm{M} / \mathrm{F}$ is seen in table 3 which is highly significant for both Europe ( $\square^{2}$ for trend 27614, p $<0.0001$ ) and for the North American Continent ( $\square^{2}$ for trend 11533, p $<0.0001)$.

The gradients are in opposite directions. More males are born at southern, warmer latitudes in Europe while more males are born in colder, northerly latitudes in the North American continent (Figure 1). There was an overall deficit of 2053687 male births based on an anticipated $\mathrm{M} / \mathrm{F}$ of approximately 0.515 (Table 3 ).

$\mathrm{M} / \mathrm{F}$ trends have reversed in some regions over the last decade (2000-9), namely in the United States and in Mexico, although the former did not reach statistical significance (table 4).

\section{Chernobyl}

$\mathrm{M} / \mathrm{F}$ in the North American continent was unaffected following the Chernobyl event of 1986. There was an upswing in M/F in Central Europe only in 1987 (figure 2), one year following the Chernobyl incident. This rise was significant (1986: males 2376490, females 2255616, 
M/F 0.51350 (CI 0.51305-0.51259); 1987: males 2378456, females 2251222, M/F 0.51420

(CI 0.51374-0.51329); $\square^{2}=4.5, \mathrm{p}=0.035$ ), returning to the previous baseline over the following two years.

\section{DISCUSSION}

\section{Latitude variation in $\mathbf{M} / \mathbf{F}$}

Latitude gradients in biological are not uncommon and not always explained. For example, it has been shown that the efficacy of the bacillus Calmette-Guérin vaccine in preventing tuberculosis varies by latitude (13).

$\mathrm{M} / \mathrm{F}$ exhibits a variable latitude gradient. The gradient exhibited in the North American continent tallies with that of the South American continent (147773689 live births), where it has been shown that $\mathrm{M} / \mathrm{F}$ increases with increasing distance from the equator (14). On the other hand, Asia (245938211 live births), which is a easterly continuation of the European landmass, exhibits a gradient direction that is similar to Europe's, with increasing $\mathrm{M} / \mathrm{F}$ in warmer and more southerly latitudes (15).

The same dataset failed to show a latitude gradient within the Nordic countries (18250193 live births comparing Iceland, Norway, Sweden and Finland with the more southern Denmark) (16) and in the post-Soviet states (115167569 live births) (17). However, a latitude gradient following that of Europe was found within the ex-Yugoslavian states (22020729 live births), with more males born toward the southern parts of this region than to the north despite there being just 7 degrees of latitude spread in this region (18). Moreover, the European latitude gradient was reversed in the United Kingdom, with the M/F excess being greater in Scotland and Northern Ireland than in England, Wales and the Republic of Ireland (49263493 live births) (19). 


\section{Secular variation in $\mathbf{M} / \mathbf{F}$}

$\mathrm{M} / \mathrm{F}$ is declining in all regions studied in this paper except for Southern Europe, resulting is an overall male deficit of 2694268 births based on an anticipated M/F of 0.515 . This trend is similar to that observed in Israel, Egypt and Kuwait (34644020 live births) (20). No such trends were observed in Australasia (17035325 live births) (21) while M/F is rising in Asia (15) and South America (14).

$\mathrm{M} / \mathrm{F}$ increases in the setting of long periods of warfare (22) but decreases with short episodes of warfare (23) and in the presence of adverse environmental factors (24) including natural disasters such as smog and floods (25), earthquakes (26), collapsing economies (27) or even due to terrorist attacks such as the September 11 events (28).

An environment that exposes women to toxins and adverse events appears to encourage such women to spontaneously abort male fetuses in excess of female foetuses (3). This has been mooted as a potential explanation for the currently observed declining $\mathrm{M} / \mathrm{F}$ in North America and Europe. It is for this reason that $\mathrm{M} / \mathrm{F}$ has been proposed as a surrogate sentinel health indicator (29). However, studies dealing with $\mathrm{M} / \mathrm{F}$ over the past 250 years indicate that the currently experienced decline in $\mathrm{M} / \mathrm{F}$ commenced prior to industrialisation and its concomitant widespread industrial pollution (30).

\section{Chernobyl}

This paper confirms that M/F rose transiently in Central Europe after Chernobyl, highlighting the potential widespread effects of radiation on $\mathrm{M} / \mathrm{F}$.

\section{CONCLUSION}

This study further extends the understanding of latitude gradients and secular trends in $\mathrm{M} / \mathrm{F}$. But to date, no reasonable explanation/s have been posited for the observed latitude variations 
in $\mathrm{M} / \mathrm{F}$, and the theory that associated the decline in $\mathrm{M} / \mathrm{F}$ with increasing industrialisation and its ensuing pollution remains an untested hypothesis.

\section{ACKNOWLEDGMENTS}

The author acknowledges the help of Mie Inoue and Gauden Galea from the World Health Organisation. There are no completing interests or source of funding to declare.

\section{REFERENCES}

1. James WH. The human sex ratio. Part 1: A review of the literature. Hum Biol 1987; 59: $721-52$.

2. James WH. The human sex ratio. Part 2: A hypothesis and a program of research. Hum Biol 1987; 59: 873-900.

3. Trivers RL, Willard DE. Natural selection of parental ability to vary the sex ratio of offspring. Science 1973; 179: 90-92.

4. James WH. The sex ratios of offspring of people exposed to non-ionising radiation. Occup Environ Med 1997; 54: 622-3. 
5. Gini C. Sulla probabilita che termini di una serie erratica sieno tutti crescenti (o non decrescenti) ovvero tutti decrescenti (o non crescenti) con applicazioni ai rapporti dei sessi nascite umane in intervalli successivi e alle disposizioni dei sessi nelle fratellanze umane. Metron 1955; 17: 1-41.

6. Grech V, Vassallo-Agius P, Savona-Ventura C. Secular trends in sex ratios at birth in North America and Europe over the second half of the 20th century. J Epidemiol Community Health 2003; 57: 612-5.

7. Grech V, Vassallo-Agius P, Savona-Ventura C. Declining male births with increasing geographical latitude in Europe. J Epidemiol Community Health 2000; 54: 244-6.

8. Grech V, Savona-Ventura C, Vassallo-Agius P. Research pointers: Unexplained differences in sex ratios at birth in Europe and North America. BMJ 2002; 324: 1010 11.

9. Scherb H, Voigt K. The human sex odds at birth after the atmospheric atomic bomb tests, after Chernobyl, and in the vicinity of nuclear facilities. Environ Sci Pollut Res Int 2011; 18: 697-707.

10. European Commision. Eurostat Statistics Database. 2014; Available at: http://epp.eurostat.ec.europa.eu/portal/page/portal/eurostat/home/. Accessed 12/12, 2013.

11. World Health Organisation. WHO Statistical Information System (WHOSIS). 2014; Available at: http://www.who.int/whosis/en/. Accessed 3/12, 2014.

12. Fleiss J. Statistical methods for rates and proportions. 2nd ed. New York: John Wiley and Sons; 1981.

13. Wilson ME, Fineberg HV, Colditz GA. Geographic latitude and the efficacy of bacillus Calmette-Guerin vaccine. Clin Infect Dis 1995; 20: 982-91. 
14. Grech V. Secular trends in sex ratios at birth in South America over the second half of the 20(th) century. J Pediatr (Rio J) 201; 89: 505-9.

15. Grech V. Secular trends and latitude gradients in sex ratio at birth in Asia during the past 60 years. Pediatr Int 2013; 55: 219-22.

16. Grech V. Sex ratios at birth in Scandinavia over the past sixty years. Scand J Public Health 2012 Dec; 40: 761-64.

17. Grech V. Secular trends and latitude gradients in sex ratios at birth in the former Soviet Republics. Acta Medica (Hradec Kralove) 2013; 56: 162-6.

18. Grech V. Secular trends and latitude gradients in the male-female ratio at birth in Yugoslavia and the ex-Yugoslavian States. Acta Medica (Hradec Kralove) 2013; 56: $47-51$.

19. Grech V. Sex ratios at birth in the British Isles over the past sixty years. Eur J Pediatr 2013; 172: 525-8.

20. Grech V. The effect of warfare on the secular trends in sex ratios at birth in Israel, Egypt, and Kuwait over the past 60 years. Libyan J Med 2014; 9: 23448.

21. Grech V. Secular trends and latitude gradients in sex ratios at birth in Australia and New Zealand (1950-2010) demonstrate uncharacteristic homogeneity. Malta Med J $2013 ; 25: 25-7$.

22. Graffelman J, Hoekstra RF. A statistical analysis of the effect of warfare on the human secondary sex ratio. Hum Biol 2000; 72: 433-45.

23. Zorn B, Sucur V, Stare J, Meden-Vrtovec H. Decline in sex ratio at birth after 10-day war in Slovenia: brief communication. Hum Reprod 2002; 17: 3173-7.

24. Grech V, Mamo J. The male to female ratio at birth. Xjenza 2014; 2: 81-90.

25. Lyster WR. Altered sex ratio after the London smog of 1952 and the Brisbane flood of 1965. J Obstet Gynaecol Br Commonw 1974; 81: 626-31. 
26. Fukuda M, Fukuda K, Shimizu T, Moller H. Decline in sex ratio at birth after Kobe earthquake. Hum Reprod 1998; 13: 2321-2.

27. Catalano RA. Sex ratios in the two Germanies: a test of the economic stress hypothesis. Hum Reprod 2003; 18: 1972-5.

28. Catalano R, Bruckner T, Marks AR, Eskenazi B. Exogenous shocks to the human sex ratio: the case of September 11, 2001 in New York City. Hum Reprod 2006; 21: $3127-31$.

29. Davis DL, Gottlieb MB, Stampnitzky JR. Reduced ratio of male to female births in several industrial countries: a sentinel health indicator? JAMA 1998; 279: 1018-23.

30 Vartiainen T, Kartovaara L, Tuomisto J. Environmental chemicals and changes in sex ratio: analysis over 250 years in Finland. Environ Health Perspect 1999; 107: 813-5. 
Table 1: Countries available for analysis, geographical distribution and missing years

\begin{tabular}{|c|c|c|}
\hline & Data from Eurostat & Missing years \\
\hline \multicolumn{3}{|l|}{ Nordic and Baltic countries $\left(>55^{\circ}\right)$} \\
\hline \multicolumn{3}{|l|}{ Finland, Iceland, Norway, Sweden, Latvia } \\
\hline Denmark & $2007-9$ & \\
\hline Estonia & & 1950-1980,1984 \\
\hline Lithuania & & 1950-1980,1984 \\
\hline \multicolumn{3}{|l|}{ Central Europe $\left(40-55^{\circ}\right):$} \\
\hline & & \\
\hline \multicolumn{3}{|l|}{ Czechoslovakia (and from 1993, Slovakia and the Czech Republic) } \\
\hline Belgium & $2008-9$ & \\
\hline France & 2009 & \\
\hline Luxembourg & 2009 & \\
\hline Romania & & $1950-54$ \\
\hline Switzerland & 2008-9 & \\
\hline UK \& Eire & 2007-9 & \\
\hline Yugoslavia (and from 1991, Slovenia, Croatia, Serbia and Montenegro and Macedonia) & $2007-9$ & Serbia and Montenegro: $1991,2004-6$ \\
\hline \multicolumn{3}{|l|}{ Southern countries $\left(35-40^{\circ}\right)$} \\
\hline \multicolumn{3}{|l|}{ Bulgaria, Greece, Malta, Portugal } \\
\hline Italy & & 2005 \\
\hline Spain & 2009 & 1970 \\
\hline North American Continent & & \\
\hline Canada $\left(>50^{\circ}\right)$, United States $\left(30-50^{\circ}\right)$ & & \\
\hline Mexico $\left(<30^{\circ}\right)$ & & $1950-57$ \\
\hline
\end{tabular}


Table 2: 5 year totals for available regions. Countries in European regions as per table 1 (CI: confidence intervals).

\begin{tabular}{|c|c|c|c|c|c|c|c|c|c|c|c|c|c|c|}
\hline & & $1950-54$ & $1955-59$ & 1960-64 & 1965-69 & $1970-74$ & $1975-79$ & 1980-84 & 1985-89 & 1990-94 & 1995-99 & 2000-04 & 2005-09 & Total \\
\hline Nordic & $\mathbf{M}$ & 894174 & 864619 & 870554 & 885565 & 805951 & 728664 & 902092 & 1047870 & 1069732 & 911245 & 881206 & 937052 & 10798724 \\
\hline countries & $\mathbf{F}$ & 842732 & 815611 & 822714 & 835599 & 755730 & 690544 & 856069 & 993021 & 1016616 & 863307 & 834606 & 889821 & 10216370 \\
\hline and & Total & 1736906 & 1680230 & 1693268 & 1721164 & 1561681 & 1419208 & 1758161 & 2040891 & 2086348 & 1774552 & 1715812 & 1826873 & 21015094 \\
\hline Baltic & UCI & 0.5156 & 0.5153 & 0.5149 & 0.5153 & 0.5169 & 0.5143 & 0.5138 & 0.5141 & 0.5134 & 0.5142 & 0.5143 & 0.5137 & 0.5141 \\
\hline States & $\mathbf{M} / \mathbf{F}$ & 0.5148 & 0.5146 & 0.5141 & 0.5145 & 0.5161 & 0.5134 & 0.5131 & 0.5134 & 0.5127 & 0.5135 & 0.5136 & 0.5129 & 0.5139 \\
\hline$\left(>\mathbf{5 5}{ }^{\circ}\right)$ & LCI & 0.5141 & 0.5138 & 0.5134 & 0.5138 & 0.5153 & 0.5126 & 0.5123 & 0.5128 & 0.5121 & 0.5128 & 0.5128 & 0.5122 & 0.5136 \\
\hline Central & $\mathbf{M}$ & 13142479 & 14212298 & 14246921 & 14027744 & 12835899 & 12071401 & 12069259 & 11848041 & 10849471 & 10024168 & 9469585 & 9568144 & 144365410 \\
\hline Europe & F & 12352908 & 13390036 & 13455285 & 13257630 & 12116131 & 11395734 & 11431821 & 11236150 & 10284451 & 9490088 & 8977887 & 9086449 & 136474570 \\
\hline \multirow[t]{4}{*}{$\left(40-55^{\circ}\right)$} & Total & 25495387 & 27602334 & 27702206 & 27285374 & 24952030 & 23467135 & 23501080 & 23084191 & 21133922 & 19514256 & 18447472 & 18654593 & 280839980 \\
\hline & UCI & 0.5157 & 0.5151 & 0.5145 & 0.5143 & 0.5146 & 0.5146 & 0.5138 & 0.5135 & 0.5136 & 0.5139 & 0.5136 & 0.5131 & 0.5141 \\
\hline & $\mathbf{M} / \mathbf{F}$ & 0.5155 & 0.5149 & 0.5143 & 0.5141 & 0.5144 & 0.5144 & 0.5136 & 0.5133 & 0.5134 & 0.5137 & 0.5133 & 0.5129 & 0.5140 \\
\hline & LCI & 0.5153 & 0.5147 & 0.5141 & 0.5139 & 0.5142 & 0.5142 & 0.5134 & 0.5130 & 0.5132 & 0.5135 & 0.5131 & 0.5127 & 0.5140 \\
\hline Southern & $\mathbf{M}$ & 5056707 & 5204219 & 5464426 & 5433908 & 4866745 & 4848583 & 4015760 & 3500504 & 3252696 & 3047078 & 3236996 & 3196073 & 51123695 \\
\hline Europe & $\mathbf{F}$ & 4767497 & 4926275 & 5162257 & 5139793 & 4589646 & 4553725 & 3764256 & 3285256 & 3057236 & 2864856 & 3043754 & 3007002 & 48161553 \\
\hline \multirow[t]{4}{*}{$\left(35-40^{\circ}\right)$} & Total & 9824204 & 10130494 & 10626683 & 10573701 & 9456391 & 9402308 & 7780016 & 6785760 & 6309932 & 5911934 & 6280750 & 6203075 & 99285248 \\
\hline & UCI & 0.5150 & 0.5140 & 0.5145 & 0.5142 & 0.5150 & 0.5160 & 0.5165 & 0.5162 & 0.5159 & 0.5158 & 0.5158 & 0.5156 & 0.5150 \\
\hline & $\mathbf{M} / \mathbf{F}$ & 0.5147 & 0.5137 & 0.5142 & 0.5139 & 0.5147 & 0.5157 & 0.5162 & 0.5159 & 0.5155 & 0.5154 & 0.5154 & 0.5152 & 0.5149 \\
\hline & LCI & 0.5144 & 0.5134 & 0.5139 & 0.5136 & 0.5143 & 0.5154 & 0.5158 & 0.5155 & 0.5151 & 0.5150 & 0.5150 & 0.5148 & 0.5148 \\
\hline Canada & $\mathbf{M}$ & 1031319 & 1187267 & 1202824 & 981174 & 911350 & 928272 & 957515 & 965920 & 1017136 & 909220 & 853227 & 935153 & 11880377 \\
\hline \multirow[t]{5}{*}{$\left(>50^{\circ}\right)$} & $\mathbf{F}$ & 974347 & 1123639 & 1139802 & 929982 & 859162 & 876651 & 906606 & 920081 & 963026 & 863172 & 809474 & 888253 & 11254195 \\
\hline & Total & 2005666 & 2310906 & 2342626 & 1911156 & 1770512 & 1804923 & 1864121 & 1886001 & 1980162 & 1772392 & 1662701 & 1823406 & 23134572 \\
\hline & UCI & 0.5149 & 0.5144 & 0.5141 & 0.5141 & 0.5155 & 0.5150 & 0.5144 & 0.5129 & 0.5144 & 0.5137 & 0.5139 & 0.5136 & 0.5137 \\
\hline & $\mathbf{M} / \mathbf{F}$ & 0.5142 & 0.5138 & 0.5135 & 0.5134 & 0.5147 & 0.5143 & 0.5137 & 0.5122 & 0.5137 & 0.5130 & 0.5132 & 0.5129 & 0.5135 \\
\hline & LCI & 0.5135 & 0.5131 & 0.5128 & 0.5127 & 0.5140 & 0.5136 & 0.5129 & 0.5114 & 0.5130 & 0.5123 & 0.5124 & 0.5121 & 0.5133 \\
\hline USA & $\mathbf{M}$ & 9778703 & 10713451 & 10660242 & 9204730 & 8638655 & 8444148 & 9321054 & 9875918 & 10384560 & 10015490 & 10391066 & 10798535 & 118226552 \\
\hline \multirow[t]{5}{*}{$\left(30-50^{\circ}\right)$} & $\mathbf{F}$ & 9292764 & 10200326 & 10158806 & 8755725 & 8204035 & 8022147 & 8884120 & 9401052 & 9902580 & 9557457 & 9917409 & 10299961 & 112596382 \\
\hline & Total & 19071467 & 20913777 & 20819048 & 17960455 & 16842690 & 16466295 & 18205174 & 19276970 & 20287140 & 19572947 & 20308475 & 21098496 & 230822934 \\
\hline & UCI & 0.5130 & 0.5125 & 0.5123 & 0.5127 & 0.5131 & 0.5131 & 0.5122 & 0.5125 & 0.5121 & 0.5119 & 0.5119 & 0.5120 & 0.5123 \\
\hline & $\mathbf{M} / \mathbf{F}$ & 0.5127 & 0.5123 & 0.5120 & 0.5125 & 0.5129 & 0.5128 & 0.5120 & 0.5123 & 0.5119 & 0.5117 & 0.5117 & 0.5118 & 0.5122 \\
\hline & LCI & 0.5125 & 0.5121 & 0.5118 & 0.5123 & 0.5127 & 0.5126 & 0.5118 & 0.5121 & 0.5117 & 0.5115 & 0.5114 & 0.5116 & 0.5121 \\
\hline Mexico & $\mathbf{M}$ & & 1559743 & 4407087 & 5107061 & 6049989 & 5329441 & 4559016 & 6731112 & 7066522 & 6843640 & 6743938 & 6486241 & 60883790 \\
\hline
\end{tabular}




\begin{tabular}{|c|c|c|c|c|c|c|c|c|c|c|c|c|c|}
\hline \multirow[t]{5}{*}{$\left(<30^{\circ}\right)$} & $\mathbf{F}$ & 1477441 & 4159606 & 4863966 & 5869843 & 5159892 & 4418639 & 6509517 & 6963152 & 6748949 & 6796424 & 6453351 & 59420780 \\
\hline & Total & 3037184 & 8566693 & 9971027 & 11919832 & 10489333 & 8977655 & 13240629 & 14029674 & 13592589 & 13540362 & 12939592 & 120304570 \\
\hline & UCI & 0.5141 & 0.5148 & 0.5125 & 0.5078 & 0.5084 & 0.5081 & 0.5086 & 0.5039 & 0.5037 & 0.4983 & 0.5015 & 0.5062 \\
\hline & $\mathbf{M} / \mathbf{F}$ & 0.5135 & 0.5144 & 0.5122 & 0.5076 & 0.5081 & 0.5078 & 0.5084 & 0.5037 & 0.5035 & 0.4981 & 0.5013 & 0.5061 \\
\hline & LCI & 0.5130 & 0.5141 & 0.5119 & 0.5073 & 0.5078 & 0.5075 & 0.5081 & 0.5034 & 0.5032 & 0.4978 & 0.5010 & 0.5060 \\
\hline
\end{tabular}

Table 3: Secular trends in M/F. Countries in European regions as per table 1 (CI: confidence intervals)

\begin{tabular}{|c|c|c|c|c|c|c|c|c|c|c|c|c|}
\hline & $\chi^{2}$ & p & Slope & Trend & Total males & Total females & Total & Male deficit & Expected males & LCI & MF & UCI \\
\hline Nordic countries and Baltic States $\left(>55^{\circ}\right)$ : & 34.2 & $<0.0001$ & $-3.7 \mathrm{E}-05$ & Decreasing & 10798724 & 10216370 & 21015094 & 24049 & 10822773 & 0.5136 & 0.5139 & 0.5141 \\
\hline Central Europe $\left(40-55^{\circ}\right):$ & 483.6 & $<0.0001$ & $-3.8 \mathrm{E}-05$ & Decreasing & 144365410 & 136474570 & 280839980 & 267180 & 144632590 & 0.5140 & 0.5140 & 0.5141 \\
\hline Southern Europe $\left(35-40^{\circ}\right)$ : & 106.6 & $<0.0001$ & $2.81 \mathrm{E}-05$ & Increasing & 51123695 & 48161553 & 99285248 & 8208 & 51131903 & 0.5148 & 0.5149 & 0.5150 \\
\hline All Europe & 232.9 & $<0.0001$ & $-2.3 \mathrm{E}-05$ & Decreasing & 206287829 & 194852493 & 401140322 & 299437 & 206587266 & 0.5142 & 0.5143 & 0.5143 \\
\hline Canada $\left(>50^{\circ}\right)$ & 11.7 & 0.000623 & $-2.1 \mathrm{E}-05$ & Decreasing & 11880377 & 11254195 & 23134572 & 33928 & 11914305 & 0.5133 & 0.5135 & 0.5137 \\
\hline USA $\left(30-50^{\circ}\right)$ & 76.4 & $<0.0001$ & $-1.7 \mathrm{E}-05$ & Decreasing & 118226552 & 112596382 & 230822934 & 647259 & 118873811 & 0.5121 & 0.5122 & 0.5123 \\
\hline $\operatorname{Mexico}\left(<30^{\circ}\right)$ & 9204.2 & $<0.0001$ & -0.0003 & Decreasing & 60883790 & 59420780 & 120304570 & 1073064 & 61956854 & 0.5060 & 0.5061 & 0.5062 \\
\hline All North America & 5402.6 & $<0.0001$ & -0.00011 & Decreasing & 190990719 & 183271357 & 374262076 & 1754250 & 192744969 & 0.5103 & 0.5103 & 0.5104 \\
\hline
\end{tabular}


Table 4: Secular trends in M/F for 2000-9. Countries in European regions as per table 1 (CI: confidence intervals)

\begin{tabular}{|c|c|c|c|c|}
\hline & $\chi^{2}$ & $\mathbf{p}$ & Slope & Trend \\
\hline $\begin{array}{l}\text { Nordic countries and Baltic States } \\
\left(>55^{\circ}\right) \text { : }\end{array}$ & 0.8 & ns & -0.00009 & $\begin{array}{l}\text { Decreasin } \\
\mathrm{g}\end{array}$ \\
\hline Central Europe $\left(40-55^{\circ}\right)$ : & 5.8 & 0.016 & -0.00007 & $\begin{array}{l}\text { Decreasin } \\
\mathrm{g}\end{array}$ \\
\hline Southern Europe $\left(35-40^{\circ}\right)$ : & 1 & ns & -0.00005 & $\begin{array}{l}\text { Decreasin } \\
\mathrm{g}\end{array}$ \\
\hline All Europe & 6.7 & $\begin{array}{r}<0.000 \\
1\end{array}$ & -0.00006 & $\begin{array}{l}\text { Decreasin } \\
\mathrm{g}\end{array}$ \\
\hline Canada $\left(>50^{\circ}\right)$ & 0.3 & ns & -0.00005 & $\begin{array}{l}\text { Decreasin } \\
\mathrm{g}\end{array}$ \\
\hline USA $\left(30-50^{\circ}\right)$ & 0.7 & ns & 0.00002 & Increasing \\
\hline $\operatorname{Mexico}\left(<30^{\circ}\right)$ & $\begin{array}{r}102 . \\
3\end{array}$ & $\begin{array}{r}<0.000 \\
1\end{array}$ & 0.00036 & Increasing \\
\hline All North America & 78.6 & $\begin{array}{r}<0.000 \\
1\end{array}$ & 0.00018 & Increasing \\
\hline
\end{tabular}




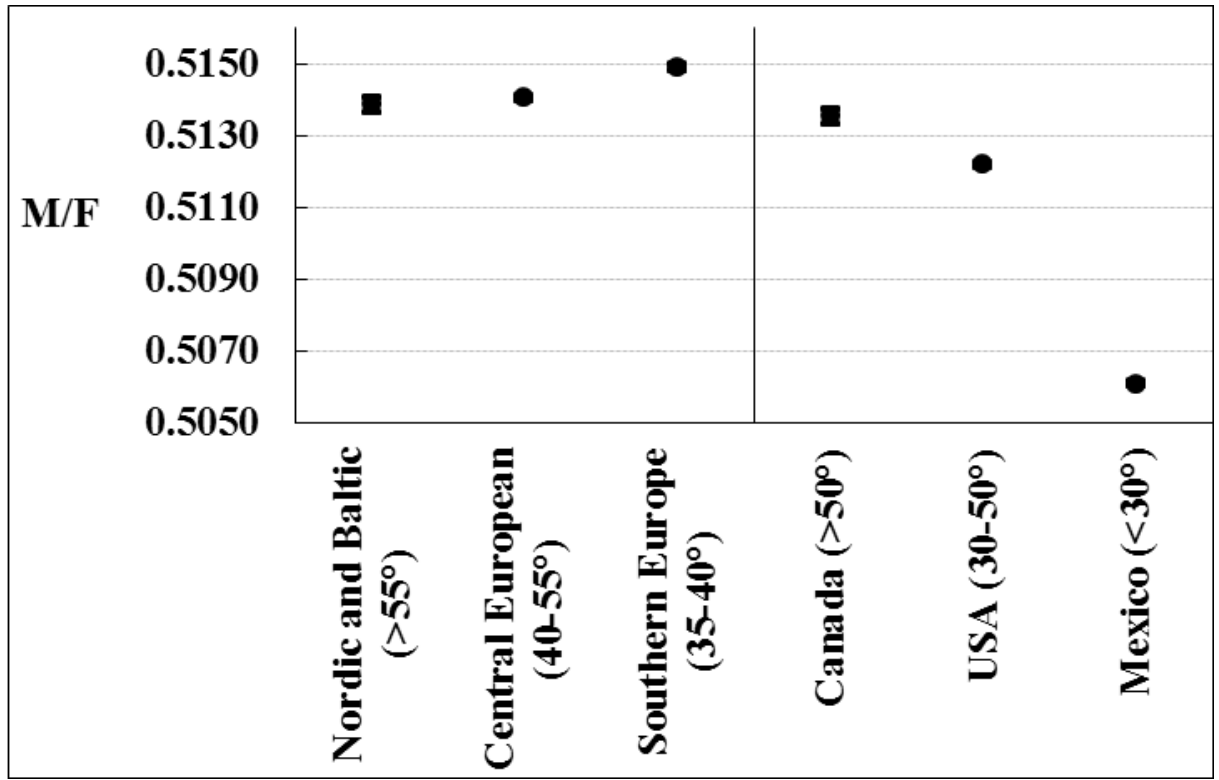

Fig. 1: M/F by latitude for Europe and North America.

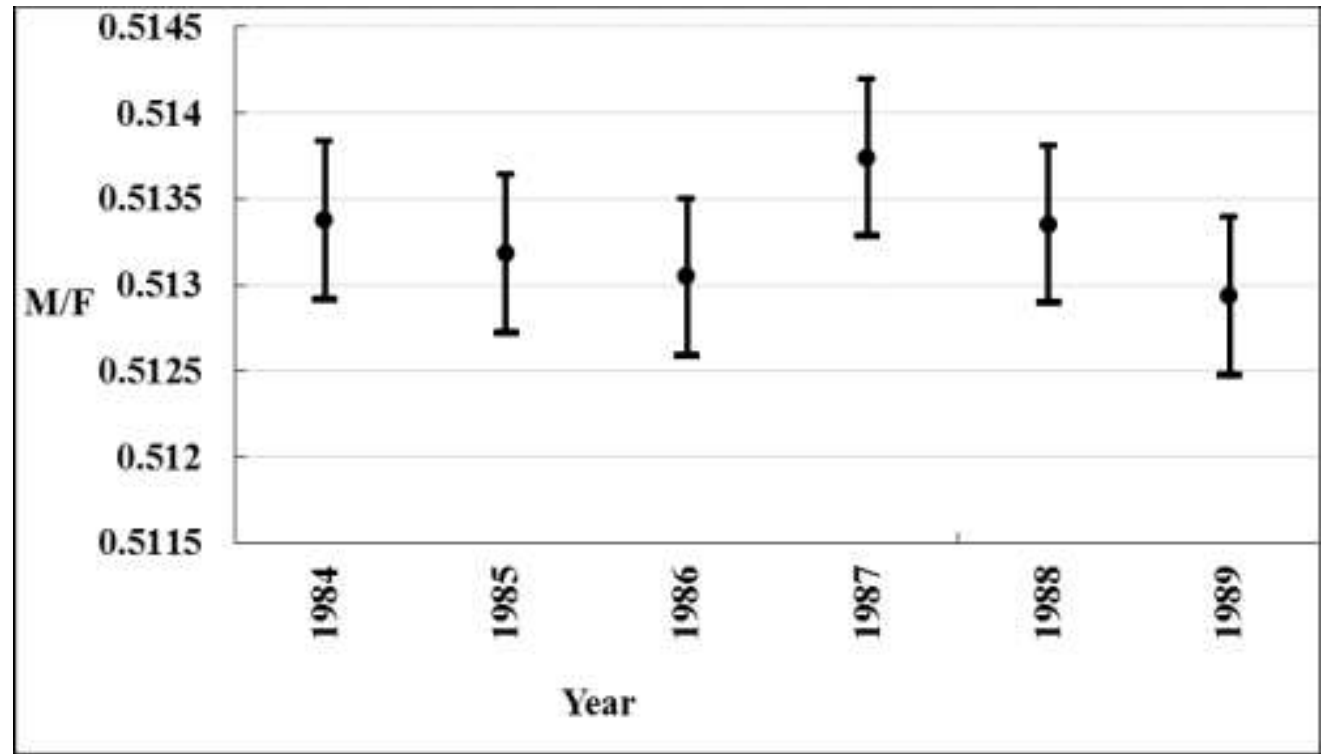

Fig. 2: M/F in Central Europe (countries as per table 1) for the period around the Chernobyl incident (1986). 